\section{Dolomitic marble from Thasos at the Louvre}

\author{
Thomas Calligaro, ${ }^{1}$ Yvan Coquinot, ${ }^{1}$ \\ Maria Filomena Guerra, ${ }^{1}$ \\ John J. Herrmann Jr., ${ }^{2}$ Ludovic Laugier, ${ }^{3}$ \\ Annewies van den Hoek ${ }^{4}$ \\ ${ }^{1}$ Research Centre of Restoration of \\ French Museums, Paris, France; ${ }^{2}$ Museum \\ of Fine Arts, Boston, MA, USA; \\ ${ }^{3}$ Department of Greek, Etruscan and \\ Roman Antiquity, Louvre Museum, Paris, \\ France; ${ }^{4}$ Harvard Divinity School, \\ Cambridge, MA, USA
}

\begin{abstract}
Many Greek and Roman sculptures in the Louvre appear to be made of coarse-grained, very white dolomitic marble from the north Aegean island of Thasos, and permission was given to test twelve of them in a non-destructive way using a mobile $\mathrm{X}$-ray fluorescence (XRF) spectrometer. Coarse-grained, white dolomitic marble sources were rare in antiquity, and if these Thasian-looking sculptures proved to be dolomitic rather than calcitic, it is highly likely that they were in fact made of Thasian marble. Ten of the twelve sculptures did prove to be dolomitic marble and therefore very probably Thasian in origin. This new information makes it possible to expand and enrich our knowledge of the exportation of marble from Thasos in both geographic and chronological terms. The tests furthermore confirm that dolomitic marble from Thasos was preferred for colossal replicas of Athena of the Velletri type and also reveal that a group of imperial portraits in Algeria were carved from marble blocks from Thasos. One test offered confirmation that a fragment in the Louvre was part of a relief in Izmir.
\end{abstract}

\section{Introduction}

Marble from the adjacent zones termed Cape Vathy and the Saliari area in the northeastern part of the northern Greek island of Thasos is characteristically almost pure dolomite. As Attanasio has pointed out (2003), it is the whitest commonly used ancient marble, and it has a maximum grain size of 1-3 $\mathrm{mm}$ with a mean of slightly less than $2 \mathrm{~mm}$, which places it among the coarse-grained marbles. Macroscopically, the stone often reveals large, glittering, flaky crystals or grains, which, together with its medium or coarse grain and unspotted whiteness, make it relatively easy to recognize by eye. The whiteness of Thasian dolomitic marble makes it an attractive material for sculpture, but its hardness makes it difficult to work. On the Mohs scale, calcite is rated 3 , while dolomite is $3.5-4.0$. Similar pure white, coarse-grained dolomitic marble suitable for sculpture is also found near Malaga in southwestern Spain and was used for sculpture at least locally in Roman times (Attanasio, 2003; Lapuente et al., 2002). Unfortunately analysis of stable isotopes of carbon and oxygen, the usual technique for marble provenancing, is of limited use in separating the dolomitic marbles of Malaga and Thasos since their signatures overlap substantially. A recent study, however, indicates that petrographic criteria can provide a basis for distinction (Lapuente et al., 2002).

Multimethod testing has shown that coarsegrained dolomitic marble like that of Thasos and Malaga was used for ancient sculpture around the Mediterranean, inland as far east as Palmyra, and on the north shore of the Black Sea (Herrmann and Newman, 1995, 2002; Wielgosz et al., 2002; Herrmann et al., 2002; Fischer, 2009). It is highly likely that this dolomitic marble comes from Thasos not Malaga. The apparent absence of Malaga marble at such Spanish centers as Merida and Zaragoza (Lapuente et al., 1999, 2002) tends to indicate that it was only used in the immediate region of the Malaga quarries during antiquity. Historical arguments reinforce this conclusion. The marble of Thasos was mentioned by ancient writers and was heavily used for sculpture on that island and in neighboring regions (Grandjean, 2000), but no ancient written source seems to mention marble from southwest Spain.

The Louvre displays many ancient sculptures that appear to be marble from Thasos. In 2007 the Département des Antiquités Grecques, Etrusques et Romaines of the Louvre granted us the opportunity to study twelve of them by nondestructive means. These pieces were chosen because their provenances offered a special geographical or historical interest. The objective of our study was to tell whether the marble was dolomite $\left(\mathrm{CaMgC}_{2} \mathrm{O}_{6}\right)$ or calcite $\left(\mathrm{CaCO}_{3}\right)$, on the assumption that, if dolomite, they came from Thasos.

\section{Materials and Methods}

The measurements were carried out in a fully non-destructive way using a mobile X-ray fluorescence (XRF) spectrometer designed at the C2RMF (Figure 1), built upon a $50 \mathrm{kV}$ molybdenum X-ray tube and a silicon-drift Xray detector (12). Measurements were made on modern breaks in order to minimize the effects of weathering. Magnesium and stron-
Correspondence: : John J. Herrmann Jr., Museum of Fine Arts, 465 Huntington Avenue, Boston, MA 02115, USA.

Tel/Fax: +1.617.267.9300.

E-mail: jherrmannjr@comcast.net

Key words: X-ray fluorescence, Greek and Roman sculpture, exportation.

Citation: Calligaro T, Coquinot Y, Guerra MF, Herrmann Jr. JJ, Laugier L, van den Hoek A, 2013. Dolomitic marble from Thasos at the Louvre. In: RH Tykot (ed.) Proceedings of the $38^{\text {th }}$ International Symposium on Archaeometry - May $10^{\text {th }}-14^{\text {th }} 2010$, Tampa, Florida. Open Journal of Archaeometry 1:e14.

Acknowledgments: the authors wish to particularly thank Alain Pasquier, formerly Head of the Department of Greek, Etruscan and Roman Antiquity, Louvre Museum, Paris, France.

Presented at the $38^{\text {th }}$ International Symposium on Archaeometry - May $10^{\text {th }}-14^{\text {th }} 2010$, Tampa, Florida.

This work is licensed under a Creative Commons Attribution 3.0 License (by-nc 3.0).

(OCopyright T. Calligaro et al., 2013 Licensee PAGEPress, Italy

Open Journal of Archaeometry 2013; 1:e14 doi:10.4081/arc.2013.e14

tium, a heavier element naturally substituting calcium, were measured in two successive runs. The magnesium and calcium X-ray lines (1.25 keV and $3.69 \mathrm{keV}$ ) were recorded operating at $15 \mathrm{kV}$ with a helium gas stream between the X-ray detector and the marble. The strontium X-ray line at $14.16 \mathrm{keV}$ was collected at 50 $\mathrm{kV}$ in air with a $50-\mu \mathrm{m} \mathrm{Zn}$ beam filter (Figure 2). XRF spectra were processed using a program based upon the fundamental parameters method. Trials performed on reference marble samples from Thasos demonstrated the ability of the XRF system to reliably measure $\mathrm{Mg}, \mathrm{Ca}$ and Sr. Under these conditions, the magnesium was measured at a depth of $7 \mu \mathrm{m}$, whereas the strontium was probed much more deeply, 1.7 and $1.1 \mathrm{~mm}$ in dolomitic and calcitic marbles respectively (the depth at which $99 \%$ of X-rays escape). The strontium concentration (ranging from 20 to $120 \mu \mathrm{g} / \mathrm{g}$ ) thus constitutes a convenient indicator of the nature of the marble, unaffected by a possible surface alteration. In addition, the markedly different $\mathrm{Sr} / \mathrm{Ca}$ ratio measured could be exploited to fingerprint Thasos marble (Figure 3).

\section{Results}

By the standards just outlined, ten of the twelve sculptures analysed proved to be 
dolomitic marble (Table 1). Most of the dolomitic pieces had a $\mathrm{MgCO}_{3}$ component between 40 and $48.6 \%$. Two, however, had a smaller $\mathrm{MgCO}_{3}$ fraction, in the neighborhood of $30 \%$ (Ma1163, 4891). This discrepancy raises the possibility of a non-Thasian origin for them. Their strontium components, however, were consistent with the rest of the dolomitic group, and at present there are no plausible dolomitic marble alternatives to Thasos. Since one of the exceptional pieces probably comes from Egypt (Ma4891), it is particularly unlikely that its marble came from an obscure quarry in Western Spain.

\section{Discussion}

The test results shed light on a variety of both archeological, and art historical problems. A Greek relief of about 560 BCE from the northern Greek island of Samothrace, MA697 (cat76;
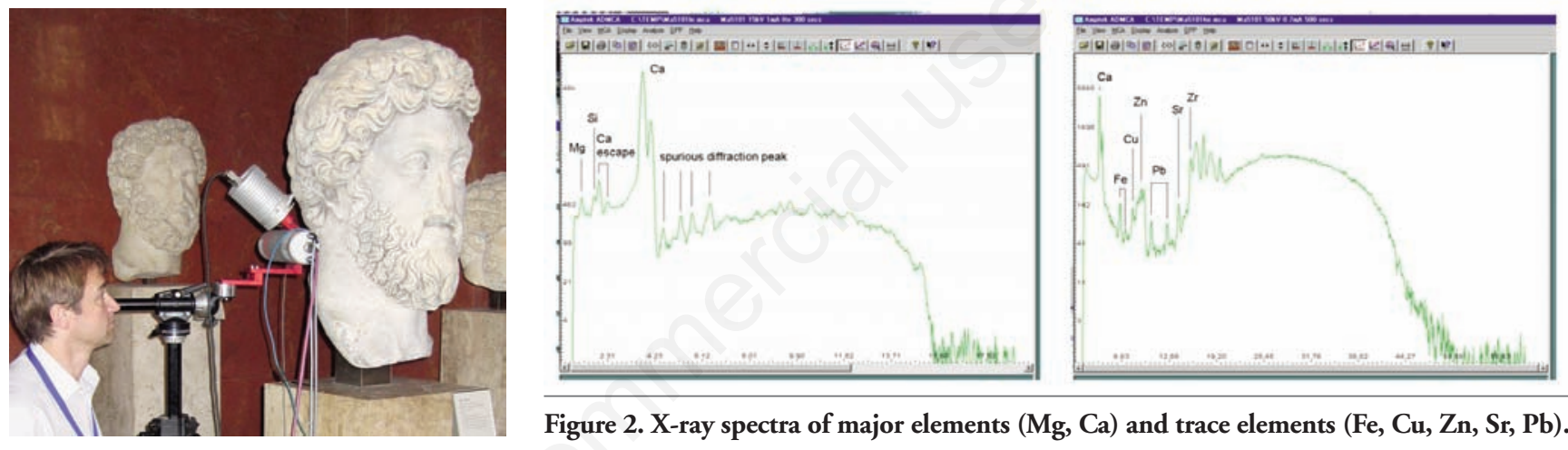

Figure 2. X-ray spectra of major elements $(\mathrm{Mg}, \mathrm{Ca})$ and trace elements ( $\mathrm{Fe}, \mathrm{Cu}, \mathrm{Zn}, \mathrm{Sr}, \mathrm{Pb}$ ).
Hamiaux, 1992), proved to have been made of calcitic rather than dolomitic marble. This is somewhat surprising since Samothrace lies only a short distance from Thasos and even at this early date, the quarries of the Cape Vathy area were in operation and had been used for relief sculpture (Grandjean, 2000). The scarcity or absence of Thasian dolomitic marble on Samothrace has already emerged in other studies of marble work on the island (Herrmann and Newman, 1999; Maniatis et al., 2012). Together, these findings make it clear that proximity and economic convenience were not the decisive criteria for the selection of marble for fine sculpture.

A dolomitic marble head, Ma 4891, is a rare case of Thasian marble exported to a distant location in Hellenistic times. The head has been dated to the late third century BCE and attributed to Egypt (cat86; Hamiaux, 1998). It can be identified as the goddess Io by the horns emerging from her forehead and could well have belonged to a statue representing the syncretistic goddess Demeter-Kore-Io-SeleneIsis (Herrmann, 1999). The body would have been made of limestone or some other material, a common technique in Greco-Roman Egypt. The Louvre sculpture Ma 4891 has much in common with another dolomitic marble head of a goddess in Copenhagen also attributed to Hellenistic Egypt (Herrmann and

The dolomitic marble sculptures in this series of tests document in various ways the diffusion of Thasian sculptural marble throughout the vast territories of the Rome Empire. Tested objects stem from the eastern shores of the Mediterranean to the Atlantic coast of France (Figure 4). The portrait of a man wearing a leafy crown of a civic dignitary, Ma3294, comes from Smyrna, modern Izmir on the Aegean coast of Turkey (cat69; Hamiaux, 1998). A head of a philosopher in dolomitic marble was bought in Syria and was probably carved there, Ma3621 (cat254; Hamiaux, 1998). A head of Sarapis, Ma1830, comes from Newman, 2002; Nielsen et al., 1997).

Figure 1. Portable X-ray fluorescence system and sculptures Ma1163 and Ma5101 of dolomitic marble presumably from Thasos.

Thasos.

Table 1. Composition of studied marble sculptures from the Louvre museum.

\begin{tabular}{|c|c|c|c|c|c|c|c|c|c|c|}
\hline $\begin{array}{l}\text { Louvre } \\
\text { inventory no. }\end{array}$ & Description & Origin & $\begin{array}{c}\mathrm{MgCO}_{3} \\
(\%)\end{array}$ & $\begin{array}{c}\mathrm{CaCO}_{3} \\
(\%)\end{array}$ & $\begin{array}{c}\mathrm{Fe} \\
(\mathrm{ppm})\end{array}$ & $\begin{array}{c}\mathrm{Cu} \\
(\mathrm{ppm})\end{array}$ & $\begin{array}{l}\mathrm{Zn} \\
(\mathrm{ppm})\end{array}$ & $\begin{array}{c}\mathrm{Sr} \\
(\mathrm{ppm})\end{array}$ & $\mathrm{Ca} / \mathrm{Sr}$ & Type \\
\hline Ma 464 & Statue of Athena & Velletri, Italy & 46.7 & 53.3 & 52 & 4 & 16 & 29 & 7320 & $\mathrm{D}$ \\
\hline Ma 697 & Relief fragment & Samothrace, Greece & 0.2 & 99.8 & 203 & 4 & 30 & 118 & 3360 & C \\
\hline Ma 1163 & Head of Commodus & Markouna, Algeria & 34.8 & 65.2 & 112 & 5 & 9 & 20 & 13100 & $\mathrm{D}$ \\
\hline Ma 1175 & Head of Faustina II & Markouna, Algeria & 48.6 & 51.4 & 71 & 6 & 13 & 28 & 7440 & D \\
\hline Ma 1346 & Dionysiac sarcophagus & Gironde, France & 48.1 & 51.9 & 64 & 12 & 8 & 28 & 7370 & D \\
\hline Ma 1830 & Head of Sarapis & Carthage, Tunisia & 45.1 & 54.9 & 33 & 7 & 0 & 23 & 9360 & D \\
\hline Ma 3294 & Crowned head & Smyrna, Turkey & 43.3 & 56.7 & 91 & 4 & 13 & 28 & 8080 & $\mathrm{D}$ \\
\hline Ma 3295 & Relief fragment & Unknown & 42.3 & 57.7 & 50 & 2 & 0 & 34 & 6880 & D \\
\hline Ma 3522 & Head of Maxentius & Langres, France & 0.0 & 100 & 50 & 3 & 11 & 116 & 3450 & $\mathrm{C}$ \\
\hline Ma 3625 & Head of Philosopher & Tortosa, Syria & 40.1 & 59.9 & 130 & 7 & 2 & 31 & 7840 & D \\
\hline Ma 4891 & Head of Arsinoé II & Egypt? & 29.5 & 70.5 & 124 & 7 & 13 & 38 & 7450 & $\mathrm{D}$ \\
\hline Ma 5101 & Head of Marcus Aurelius & s Markouna, Algeria & 41.7 & 58.3 & 71 & 6 & 13 & 22 & 10400 & D \\
\hline
\end{tabular}

Mg, magnesium; Ca, calcium; Fe, iron; Cu, copper; Zn, zinc; Sr, strontium; D, dolomitic; C, calcitic. 


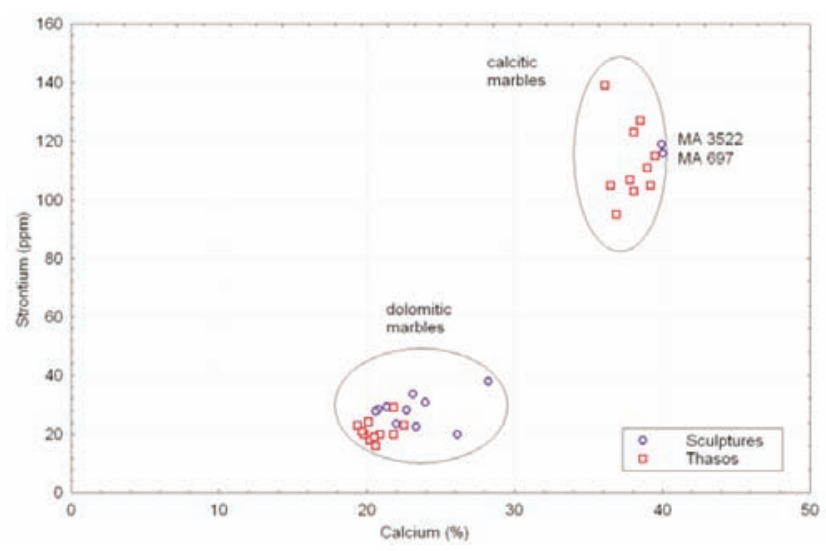

Figure 3. Strontium $v s$ calcium plot discriminating calcitic and dolomitic marbles.

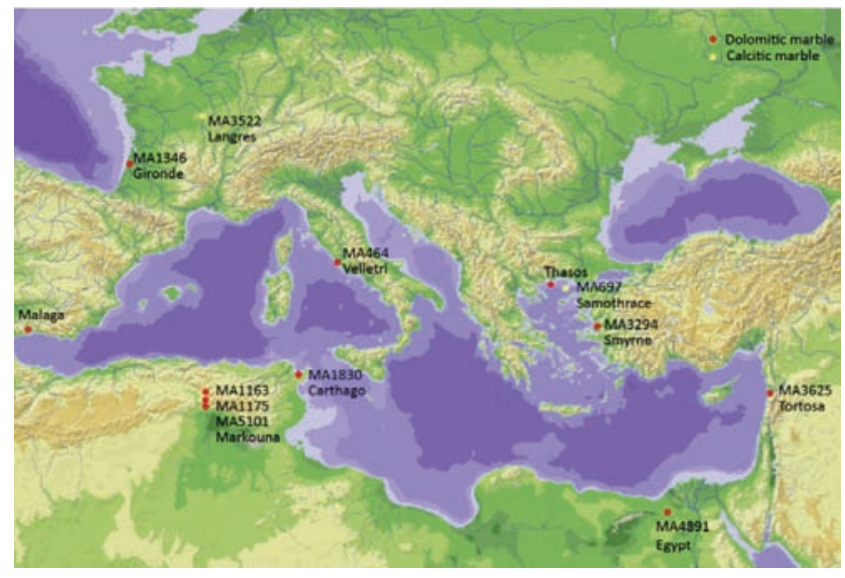

Figure 4. Map showing the location of the sculptures studied and Thasos and Malaga, ancient sources of dolomitic marble.

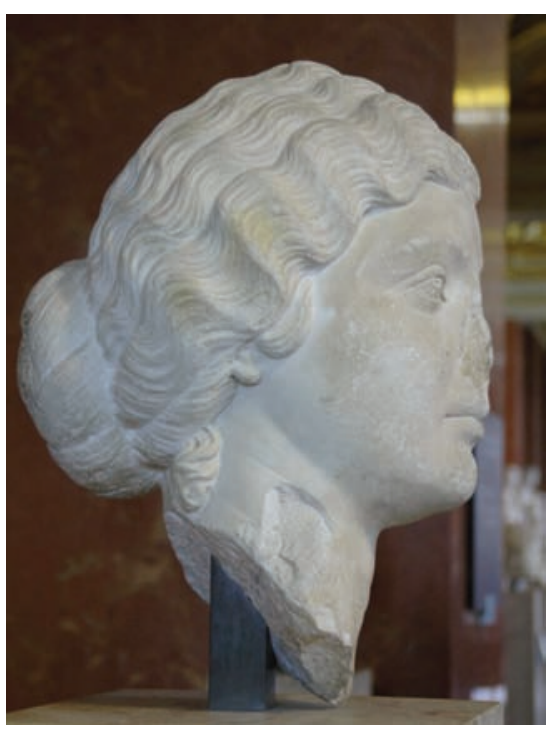

Figure 5. Portrait of Faustina II, empress 161-175 AD, found at Markouna, Algeria, Louvre, Ma 1175; dolomitic marble presumably from Thasos.

Carthage in Tunisia (Atlas database, 2010). A sarcophagus of dolomitic marble decorated with figures in Rome, Ma1346, was found at Saint-Médard-Eyrans, near Bordeaux (Baratte and Metzger, 1985; Astier, 2010). This heavy object must have been transported from Rome to western Gaul via the Atlantic Ocean.

Some of the tests shed light on the processes that led to the use of Thasian marble. Such is the case of the colossal statue of Athena, Ma464 (height $3.05 \mathrm{~m}$ ). The statue, which was found at Velletri near Rome, is a perfect match in all respects including its marble for colossal replicas of this type of Athena in the Musei Capitolini, Rome and the Yale Art Gallery, New Haven (Herrmann and Newman, 1995, 2002).
The other colossal replicas of this type seem to be made of fine-grained marble quarried on Mt. Pentelicon near Athens. The Roman sculptors must have ordered specially shaped blocks from the two quarries for these exceptionally large commissions.

Three imperial portraits dating from the Antonine period (138 $192 \mathrm{CE}$ ) found together at Markouna/Verecunda in Algeria are made of dolomitic marble (Ma1163, 1175 and 5101). Their differing analytical characteristics indicate that the heads were not extracted from the same block. The portraits are evidently the work of two ateliers, one provincial or, in any case, distinctly North African (Ma1163, Ma5101) (cat149; Baratte, 1983; de Kersauson, 1990; cat34; Baratte, 2003) (Figure 1) and the other highly cosmopolitan or central Italian (Ma1175) (cat.110; Baratte, 1983; de Kersauson, 1990; cat29; Baratte, 2003) (Figure 5 ). The sculptor of the sophisticated portrait of the empress Faustina II (Ma1175) (Figure 5) evidently came from Rome, and he may have had a preference for Thasian marble, since a very similar portrait of Faustina in dolomitic marble is preserved there in the Museo Nazionale Romano (Herrmann and Newman, 1995; Felletti Maj, 1953). Baratte has observed that the Roman piece is slightly inferior in quality (cat29; Baratte, 2003), but even so the two works could have been produced by sculptors who were associated, if not members of the same workshop. The Roman sculptor may well have procured or ordered the supply of marble from Thasos, and he may have hired the local workshop to help him complete the project in Markouna. Since the local North African sculptor or sculptors also used Thasian marble, either the availability of the material or the preference of the Roman artist probably dictated the choice.

One of the tests made it possible to confirm the origin of a sculpture in the Louvre. A frag- mentary relief in dolomitic marble shows a figure with crossed legs against an unusual background of simulated masonry, Ma3295. The same unusual background appears in a fragmentary relief with Poseidon from the agora of Smyrna, and the two reliefs have long been thought to come from the same monument (Naumann and Kantar, 1950; Dedeoglu, 1993). The Smyrna relief is also made of coarsegrained dolomitic marble and is likewise Thasian (Herrmann and Newman, 1995). The Louvre fragment, Ma3295, however, has been identified as Parian marble, and the reliefs have been attributed to an Athenian workshop (Naumann and Kantar, 1950). The use of northern Greek marble now suggests a local Asiatic origin for the workshop. Several comparable first- and second-century reliefs in western Asia Minor were made of dolomitic Thasian marble (Herrmann and Newman, 1995). The region from Smyrna to Ephesus appears to be the only region outside of Macedonia where dolomitic Thasian marble was used for large-scale relief sculpture, and the Smyrna relief now can be seen as full member of that tradition.

\section{Conclusions}

The identification of ancient marble sources usually requires sampling and multimethod testing. The case of pure-white, coarsegrained dolomitic marble, however, presents an exception to this rule, since Thasos is virtually the only ancient source for marble with these characteristics. A single scientific test to determine whether the marble is calcite or dolomite can therefore establish the quarry of origin (Thasos) with a high degree of confidence. An experienced eye is a useful adjunct in identifying candidates for testing. 
Making use of the completely non-destructive technique of X-ray fluorescence, it has been possible to identify ten Thasian dolomitic marble sculptures in the Louvre collection. These sculptures come from widely scattered sites around the Roman Empire, shed light on the practices of Roman sculptural workshops, and clarify the genesis of a monument divided between Turkey and the Louvre.

\section{References}

Astier M-B, 2010. Sarcophagus with the myth of Dionysos and Ariadne. Louvre Museum, Paris. Available from: http://www.louvre.fr/ en/node/25425

Atlas database. Louvre Museum, Paris. Available from: http://cartelen.louvre.fr/ cartelen/visite?srv=car_not_frame\&idNot ice $=20062 \&$ langue $=$ en

Attanasio D, 2003. Ancient white marbles: analysis and identification by paramagnetic resonance spectroscopy. L'Erma di Bretschneider, Rome.

Baratte F, 1983: [Les portraits imperiaux de Markouna et la sculpture officiel dans l'Afrique romaine]. [Article in French]. Mélanges de l'École Française de Rome 95:791-4.

Baratte F, 2003. [Algérie antique]. [Book in French]. Musée de l'Arles et de la Provence antiques, Avignon, pp 33-4.

Baratte F, Metzger C, 1985. [Musée du Louvre. Catalogue de sarcophages en pierre d'époques romaine et paléochrétienne]. Louvre Museum, Paris, pp 138-42.

Calligaro T, Dran J-C, Klein M, 2003. Application of photo-detection to art and archaeology at the C2RMF. Nucl Instrum Meth A 504:213-21.

Dedeoglu J, 1993. Izmir Archaeological Museum. A Turizm Yayinlari, Istanbul, pp 74 .

de Kersauson K, 1990. [Musée du Louvre, Catalogue des portraits romains II: de l'année de la guerre civile (68-69 après J.-C.) à la fin de l'Empire]. [Book in French]. Réunion des musées nationaux, Paris.

Felletti Maj BM, 1953. [Museo Nazionale Romano: i ritratti]. [Book in Italian]. Libreria dello Stato, Rome.

Fischer M, 2009. Marble from Pentelicon, Paros, Thasos and Proconnesus in ancient Israel: an attempt at a chronological distinction. In Y. Maniatis (ed.) ASMOSIA VII. Proceedings of the 7th International Conference of the Association for the Study of Marble and Other Stones in
Antiquity, pp 399-412.

Grandjean Y, Salviat F, 2000. [Guide de Thasos]. [Book in French]. École Française d'Athènes, Paris.

Hamiaux M, 1992. [Musée du Louvre, Département des Antiquités Grecques, Étrusques et Romaine. Les sculptures grecques I: des origines à la fin du IVe siècle avant J.-C]. [Book in French]. Réunion des Musées Nationaux, Paris.

Hamiaux M, 1998. [Musée du Louvre, Département des Antiquités Grecques, Étrusques et Romaines. Les sculptures grecques II: la période hellénistique (IIIeIe siècles avant J.-C.)]. [Book in French]. Réunion des musées nationaux, Paris.

Herrmann J, 1999. Demeter-Isis or an Egyptian Demeter? A Greco-Roman sculpture from an Egyptian workshop in Boston. Archaeol Anz 114:65-123.

Herrmann J, Newman R, 1995. The exportation of dolomitic sculptural marble from Thasos: evidence from Mediterranean and other collections. In: Y. Maniatis, N. Herz, Y. Basiakos (eds.) The study of marble and other stones used in antiquity. Proceedings of the 3rd International Symposium of the Association for the study of marble and other stones used in antiquity, Athens 1993. Archetype, London, pp 73-86.

Herrmann J, Newman R, 1999. Dolomitic marble from Thasos near and far: Macedonia, Ephesos, and the Rhone. In: M. Schvoerer (ed.) [Archéomateriaux: marbres et autres roches]. [Proc. in French]. Proceedings of the 4th International Conference ASMOSIA IV, France, Bordeaux-Talence, 9-13 October 1995. Presses Universitaires de Bordeaux, Bordeaux, pp 293-303.

Herrmann J, Newman R, 2002. New sculptures in Thasian dolomite: Turkey, Greece, Egypt, Italy. In: J. Herrmann, N. Herz, R. Newman (eds.) ASMOSIA V: interdisciplinary studies on ancient stone. Proceedings of the Fifth International Conference of the Association for the study of Marble and other stones in antiquity, Museum of Fine Arts, Boston, 1998. Archetype, London, pp 215-24.

Herrmann J, van den Hoek A, Newman R, 2002. New sculptures in Thasian dolomite: Ukraine, Tunisia, and questions of style. In: L. Lazzarini (ed.) ASMOSIA VI: interdisciplinary studies on ancient stone. Proceedings of the Sixth International Conference of the Association for the study of marble and other stones in antiquity, Laboratorio di Analisi dei Materiali
Antichi, IUAV, 2000. Morseletto, Vicenza, pp 357-62.

Lapuente P, Preite Martinez M, Turi B, Blanc P, 2002. Characterization of dolomitic marbles from the Malaga province (Spain). In: J. Herrmann, N. Herz, R. Newman (eds.) ASMOSIA V: interdisciplinary studies on ancient stone. Proceedings of the fifth International Conference of the Association for the Study of Marble and other Stones in Antiquity, Museum of Fine Arts (Boston, 1998). Archetype, London, pp 152-62.

Lapuente P, Turi B, Blanc P, 2009. Marbles and coloured stones from the Theatre of Caesaraugusta: preliminary study. In Y. Maniatis (ed.) ASMOSIA VII. Proceedings of the 7th International Conference of Association for the Study of Marble and other Stones in Antiquity. Ecole française d'Athenes, Athenes, pp 509-522.

Lapuente P, Turi B, Lazzarini L, Nogales T, 1999. Provenance investigation of white marble sculptures from Augusta Emerita, Hispania, In Schvoerer M (ed.) [Archéomateriaux: Marbres et autres Roches] [Proc. in French]. Proc. of the IV International Conference ASMOSIA IV (Bordeaux-Talence, 9-13 octobre 1995), Université de Bordeaux 3/CNRS. Presses Universitaires de Bordeaux, Bordeaux, pp 111-6.

Maniatis Y, Tambakopoulos D, Dotsika E, Wescoat BD, Matsas D, 2012. The sanctuary of the Great Gods on Samothrace, Greece: an extended marble provenance study. In: M.A. Guttierez Garcia, P. Lapuente, I. Rodà (eds.) Interdisciplinary studies on ancient stone. Proceedins of the IX ASMOSIA Conference (Tarragona, 2009). Istituto Català d'Arqueologia Clàssica, Tarragona, pp 263-78.

Naumann R, Kantar S, 1950. [Die Agora von Smyrna]. [Book in German]. Istanbuler Forschungen, Berlin, pp 69-114.

Nielsen AM, Østergaard J, Moltesen M, Lundgreen B, 1997. The Eastern Mediterranean in the Hellenistic period: Ny Carlsberg Glyptotek: catalogue. Glyptotek, Copenhagen.

Wielgosz D, Lazzarini L, Turi B, Antonelli F, 2002. The origin of the marble sculptures from Palmyra. In: L. Lazzarini (ed.) ASMOSIA VI: interdisciplinary studies on ancient stone. Proceedings of the 6th International Conference of the Association for the Study of marble and other stones in antiquity. Morseletto, Vicenza, pp 389-401. 